\title{
Sector specific features of innovative development in the Russian economy
}

\author{
I.A. Krasyuk ${ }^{1 *}$, V.V. Bakharev ${ }^{1}$, and Y.Y. Medvedeva ${ }^{2}$ \\ ${ }^{1}$ Saint Petersburg Polytechnic University Peter the Great, 195251 Saint-Petersburg, Russia \\ ${ }^{2}$ Don state technical university, 344000 Rostov-on-Don, Russia
}

\begin{abstract}
The present-day development of the Russian Federation is mostly shaped by the innovative development capacity of the national economy. Industry forms the core of such development. The paper presents the study of the current state of the innovative development in industry being the source of the basic innovations, as well as identifies the limitation factors. The authors have found out that low innovative activity of the industrial enterprises holds back the implementation of innovations in the related sectors, for instance, trade. It has also been found out that the course of the innovative development in the field of trade is also shaped by the sector-specific factors, which should be considered to adjust the innovation policy of a trading enterprise.
\end{abstract}

\section{Introduction}

To function successfully in the modern ever-changing environment, an enterprise requires efficient innovations management. Innovative development in multiple fields of the market economy features various peculiarities, impacting its efficiency. The innovative development of the Russian industrial enterprises is presently shaped by a number of external factors, and is largely determined by the structural shifts and imbalances of the Russian economy, and depends on the degree of the internal enterprise potential utilization.

\section{Relevance}

The activities of the modern industrial enterprises are largely shaped by the modern industrial and commercial policy, the state and the developmental prospects of the Russian retail trade. The development of the latter is mostly considered to be defined by the market influence of the retail chains. The regional expansion of the major retail food store chains usually features purchasing of local structures chains of the required form and scope as well as franchising. Trading enterprises are forced to use innovative methods, which allow for the arrangement of the shopping space planning, modeling the functioning of the stores, setting up the staff schedules. As the customers' incomes increase, and the customers become more discerning, they can be segmented into smaller market groups. With the quickly changing and flexible market most of the retail sellers are forced to introduce new products, enter new international markets, or take some shares of the market over from the competitors. Thus the efficient innovative activity in trade can provide the commercial enterprises with the required competitiveness level.

The study of approaches to the innovation management shows that the peculiar features of the innovative development mechanism formation are quite well-established. J. Schumpeter, an American and Austrian economist considered as the founder of the innovations concept, defined innovations as a new combination of the factors of production motivated by entrepreneurial spirit [1]. 2. Clayton M. Christensen, Michael E. Raynor developed the ideas on the innovative development by specifying basic notions, extending the typology and the array of innovations management methods [2]. P. Druker, D.Stiglic studies the opportunities for business development based on innovation implementation $[3,4]$.

J. Schumpeter defines basic and secondary innovations. Trade, with its peculiarities and features different from production, is the field for secondary innovations. It is impossible to pass the accumulated experience in innovation activity organization from other fields over to trade. Quite few authors study the innovative development, and innovation changes in the field of trade, and their typology. The leader among those is B. Hallier, the founder of EHI Retail Institute, who studies the retail trade modes and formats genesis [5].

\section{Studied problem and hypothesis}

The core problem of the present research consists in the resolution of the controversy existing between the large number of new developments in the fields of information technology, marketing, and trade, which are potentially applicable in successful commercial companies, and the

Corresponding author: iri-krasjuk@yandex.ru 
inefficient use of these instruments in the enterprise management. Based on this problem, the following hypothesis can be suggested. The organization of efficient innovation activity of a trade enterprise is based on the study and establishing the system of a large number of defining factors to select the most efficient management alternative in the field of innovations policy.

\section{Theoretical part}

Modern innovation theory understands an innovation as the ultimate result of the innovative activity delivered in the form of a new or modernized technological process, technology, product, or service. The 2016 GII (The Global Innovation Index) data, presented in Table 1, show that Russia is consistently improving its rank [6]. The improving of innovative activity efficiency is very much dependent on the effectiveness, employability, and tradeability of innovations.

Table 1. The dynamics of Russia's position in GII in 20142016.

\begin{tabular}{|c|c|c|c|c|}
\hline Years & GII & $\begin{array}{c}\text { Resources } \\
\text { of } \\
\text { innovation }\end{array}$ & $\begin{array}{c}\text { The results } \\
\text { of } \\
\text { innovation }\end{array}$ & $\begin{array}{c}\text { The } \\
\text { effectiveness of } \\
\text { innovation }\end{array}$ \\
\hline 2016 & 43 & 44 & 47 & 69 \\
\hline 2015 & 48 & 52 & 49 & 60 \\
\hline 2014 & 49 & 56 & 45 & - \\
\hline
\end{tabular}

The innovations implemented in industrial production will allow for a considerably greater pace of modernization processes, and stronger competitiveness of the country. With the import substitution policy in place filling the consumer market in with the goods produced in Russia, both food and non-food, becomes very important. The development of the internal market and meeting the consumer demand allow solving a wide range of tasks, including but not limited to the employment generation, increase in the tax base, lowering social tension, industrial diversification process development, etc. The efficient functioning of commerce provides for the interconnection of trade and production, boosts business activity, stimulates the implementation of innovation.

The innovative development of trade features the industrialization of major commercial processes, establishment of the integrated information and technology product distribution system, implementation of advanced product retail modes, establishment of direct production - consumption links, building up regional electronic trade infrastructure, setting up a bank of electronic product passports [7]. The development of chain retailing brings forward the issues of commercial businesses management modernization. More rigorous competition creates the conditions stimulating further implementation of innovations. The innovative instruments which can be used in the activity of the trading organizations are organizational and managerial in character.

The innovative environment is based on the development of creative thinking, which secures bigger competitive advantage. Creative thinking is the search for novel, original problem solving approaches, creating the conditions stimulating innovative thinking, securing better commercial innovations output; it is performed in different - micro-, meso-, and macro-economic - levels [8].

Innovative activity in trade tends to be continuous, while taking the form of a stage-by-stage process. Regional factors can influence the innovative activity of the trade enterprises, so the discovery of the regional differences facilitates the development of the innovative processes in trade. When conducting the innovative activity in trade, one has to account for the specific peculiarities of the commercial sector. The innovative development in trade unfolds at various stages of the commercial and technological process.

Thus the innovations in trade are usually associated with the improvement of the existing service and commercial and technological novelties, while marketing innovations are also of high importance as the consumers influence the producers indirectly via trade. Moreover, major trade companies, being at the leaders of the sectoral innovative development also have major impact in this respect. Trade and commerce are characterized by the emergence of innovations, which are generated both inside them and in the related sectors, primarily, in production. The implementation of innovative management results in the higher added value of the service for the end consumers, more efficient trade and technological process, increased competitiveness, more precise satisfaction of the consumer demand, he emergence of new trade formats, modes, forms, methods and technologies, improved product quality, and wider product range [11]. To implement such innovations a trade enterprise has to use all of its potential, including talent, finance, technology, information, equipment, and marketing.

\section{Research application}

The level of innovation development is reflected in the general R\&D potential of the industry, the core of innovations and the crucial component of the innovations environment for the trade companies, providing for the goods circulation. According to the State Statistics Service of the Russian Federation the share of the organizations performing innovations in technology in Russia in 2014, 2015, and 2016 equaled 10,1\%, 9,9\% and $9,3 \%^{\mathrm{a}}$, while the share of innovative products in the total volume of goods and service produced equaled 11,2 in $2013,12,8 \%$ in 2014 , and 12,9 in 2015. (Fig. 1.)

Sectoral components characterize the innovative potential and the prospects of the sector depending on its specific peculiarities. As the trade sector is where the commercial services are provided and the goods circulation is executed, the innovative activity in this field is not material in its form, which means that the novelties mostly concern the trade processes and technology, marketing, sales methods [12].

\footnotetext{
${ }^{\mathrm{a}}$ The state statistics Committee of the Russian Federation
} 


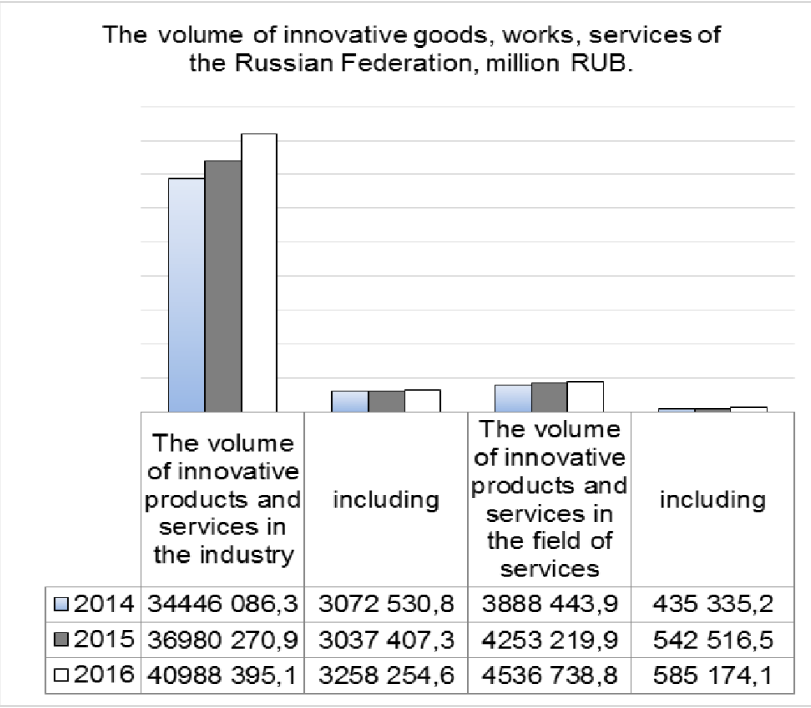

Fig. 1. The volume of innovative goods, works, services in the Russian Federation, million RUB ${ }^{\mathrm{b}}$.

The analysis of the investment in the development of trading activity by the retail trade companies shows that equipment modernization and renewal expenditure was cut down in 2014, the trend for advertising budgets cut down is also present (Fig. 2).

However, despite the complex economic situation, the share of no expenditure has also decreased. The dynamics of the innovative goods in the services sector, where trade belongs in terms of the Russian classification, is still very insufficient.

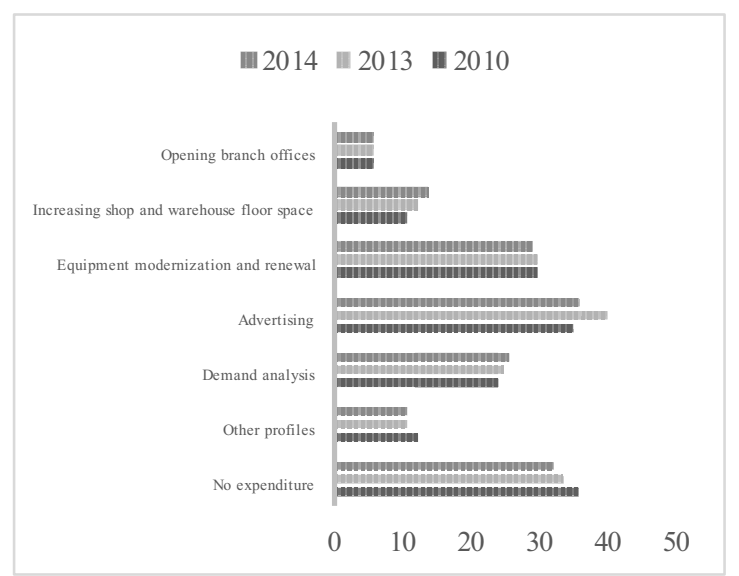

Fig. 2. The designation of development resources of the Russian trade organizations, Percent ${ }^{\mathrm{c}}$.

The Russian commodity circulation per capita, which is a proxy indicator of both nationwide and regional socio-economic state as of 01.01.2016 equaled 188,000 RUR. However, the regional distribution is extremely uneven. For instance, the Central Federal District has 237,700 RUR per capita, while the North Caucasus Federal District and the Siberian Federal District levels are 155,700 RUR and 141,800 RUR. Consequently, the

\footnotetext{
${ }^{\mathrm{b}}$ lbid

${ }^{\mathrm{c}}$ lbid
}

distribution of the retail commodity turnover according to the territory shows the uneven character of development of this sector of the regional consumer market, thus manifesting the regional irregularity of the supply and demand. Taking into account that the difference in income per capita in different territories of the Russian Federation is negligible, one can conclude that such a lag in product turnover per capita can indicate the lack or insufficiency of retail trade enterprises in several regions of the country [13].

With the low floor space availability and insufficient product turnover the innovative development of the Russian retail trade is stagnating. The factors capable of kick starting the innovative development mechanisms in the sector are those related to the competition and the innovative development in industry, being the source of basic innovations.

On the other hand, the Russian industry sector, impacted by major market turbulence, may not serve as the source of the innovative development of the required level. Low rate of acquisition of technology by the business fails to generate the demand for innovation as the major factor of production and the source of growth and competitiveness. Private investors do not support public investment expenditure, which results in the Russian industry falling back in terms of the number of innovative companies and the share of innovative products and services.

The experts ${ }^{\mathrm{d}}$, consider the following factors to be the barriers for the innovative development of the industry: - Low return on public and private investment in innovation;

- The innovative markets are low-competition markets due to low demand for innovation;

- Lack of institutional and legal regulations for the interaction of the innovation owners and investors;

- The inability to attract and keep talent, active in the field of innovation.

There exist both the general parameters, determining the sectoral innovative development, and a range of specific factors, doing so (Table 2).

Table 2. Factors of innovative development of Russian industry and trade.

\begin{tabular}{|c|c|c|}
$\begin{array}{c}\text { Specific } \\
\text { for the Russian } \\
\text { industry } \\
\text { the parameters of } \\
\text { innovative } \\
\text { development }\end{array}$ & $\begin{array}{c}\text { Common factors of } \\
\text { innovative } \\
\text { development }\end{array}$ & $\begin{array}{c}\text { Specific } \\
\text { for Russian } \\
\text { trade } \\
\text { the parameters } \\
\text { of innovative } \\
\text { development }\end{array}$ \\
\hline $\begin{array}{c}\text { Low interest of the } \\
\text { in innoj businesses }\end{array}$ & $\begin{array}{c}\text { Low demand for } \\
\text { innovation }\end{array}$ & $\begin{array}{c}\text { High sectoral } \\
\text { competition }\end{array}$ \\
\hline $\begin{array}{c}\text { Innovative markets } \\
\text { are low- }\end{array}$ & $\begin{array}{c}\text { Insufficient level of } \\
\text { human capital } \\
\text { acquisition and } \\
\text { development }\end{array}$ & $\begin{array}{c}\text { The influence of } \\
\text { foreign trade } \\
\text { companies } \\
\text { being the } \\
\text { leaders of } \\
\text { innovative } \\
\text { activity in the } \\
\text { market }\end{array}$ \\
\hline Low return on & Irregular legal and & High importance \\
\hline
\end{tabular}

${ }^{\mathrm{d}}$ National report on innovation in Russia-2016 


\begin{tabular}{|c|c|c|}
\hline $\begin{array}{c}\text { public and private } \\
\text { investment }\end{array}$ & $\begin{array}{c}\text { institutional } \\
\text { innovations } \\
\text { infrastructure }\end{array}$ & $\begin{array}{c}\text { of marketing } \\
\text { innovations } \\
\text { (consumers } \\
\text { influence the } \\
\text { producers } \\
\text { indirectly via } \\
\text { trade) }\end{array}$ \\
\hline
\end{tabular}

These groups of parameters should be reviewed separately to improve the efficiency of managerial decisions in the field of innovations policy.

\section{Conclusions}

The elicited peculiarities of innovation activity in industry and trade allow for the evaluation of the promising innovative development profiles for both sectors. For instance, due to the issues in the industry innovative development, Russian retailers should not expect gaining access to affordable Russian product innovations. However, process, technological, and marketing innovations can presently serve as the alternative instruments for the innovative development of trade.

In the present conditions the retailers try to cover several profiles at once to absolutely dominate the market: they select the sales spot with maximum customer traffic, attract many loyal customers, while cutting down the shop floor and equipment usage costs to minimum levels, increase the profitability of the company along with higher average purchase cost. Though, usually such « rush » pushes the customer satisfaction issue aside, which is a critical error for a business selling goods and services. Standard, traditional marketing instruments are trite for the modern consumer, who is lost among similar products, loses interest to the brand of the shop. This situation calls for the innovations, which would make radical change to the image of the company, while the major such innovations should come from marketing, the dominant aim of which is to plant the ideas capable of meeting the demands of the most discerning customer.

Innovative development can play a major role when such decisions are made. The stock, staff, and the shop floor constitute the most important resources for a retail trader, while the rigorous overall control over them is of crucial importance to maintain one's competitive position.

\section{References}

1..Y. Shumpeter, Theory of economic development: monograph (Progress, Moscow, 1982)

2. Clayton M. Christensen, Michael E. Raynor, The Innovator's Solution: Creating and Sustaining Successful Growth (Alpina Pablisher, Moscow, 2016)

3. P. Druker, Business and Item innovations Druker (Williams, Moscow, 2007)

4. D. Stiglic, Steep Dive: America and the New Economic Order after the Global Crisis (Eksmo, Moscow, 2011)

5. B. Hallier, Modern Stores: A History of Technical Development (Interekspert, Moscow, 2009)

6. Innovation in Russia. Official website. http://innovation.gov.ru/ru/node/75123.

7. I.A. Krasyuk, Practical Marketing, 6, 8-18 (2015)

8. I.A. Krasyuk, N.G. Kuznetsov, Yu.Yu. Medvedeva, T.S. Stepchenko, V.P. Fedko, Marketing, trading (Rostov-on-don, 2013)

9. National report on innovations in RUSSIA-2016. http://www.rvc.ru

10. Federal State Statistics Service. http://www.gks.ru.

11. Yu.Yu. Medvedeva, Modern science: actual problems of theory and practice. Series: law and Economics, 4, 68-73 (2016)

12. I.A. Krasyuk, Modern science: actual problems of theory and practice. Series: law and Economics, 12, 87-91 (2014)

13. Yu.Yu. Medvedeva, Synthesis of science and society in the solution of global problems of the modern world: collected articles of International scientific practical conference, 68-75 (2016) 